\title{
FOLKLORE AND SOCIAL SCIENCE LEARNING MODEL IN ELEMENTARY SCHOOL IN BALI
}

\author{
I Nengah Suastika \\ Civic Education Department Universitas Pendidikan Ganesha
}

Ketut Sedana Arta and *Ni Made Ary Widiastini History Department Universitas Pendidikan Ganesha

Submitted: 18-10-2018; Revised:09-05-2019; Accepted: 09-05-2019

\begin{abstract}
ABSTRAK
Cerita rakyat adalah media strategis untuk proses pendidikan, yaitu ekspositori dan humanistic, untuk anak-anak. Melalui cerita rakyat, anak-anak memiliki perspektif, nilai-nilai, dan orientasi yang rasional, realistis sesuai dengan budaya yang mereka miliki. Akan tetapi, perkembangan media digital dengan segala kecanggihannya sering menghilangkan nilai-nilai budaya anak-anak. Anakanak kehilangan karakter idola mereka yang dapat digunakan sebagai panutan, terasing dari nilainilai budaya mereka sendiri, dan kehilangan identitas mereka di tengah perkembangan besar-besaran dalam informasi digital. Seperti pandangan Bourdieu tentang habitus sebagai seperangkat nilai, praktik dan kecenderungan batin, di mana habitus dapat terus berkembang (generatif) dan ditransfer dari satu domain ke domain lain. Dalam praktiknya, kehadiran media digital ternyata berdampak pada pencabutan nilai-nilai budaya yang harus diterima oleh anak-anak sejak usia dini karena digantikan oleh perkembangan teknologi. Memahami fenomena tersebut, penelitian ini mengkaji pengembangan pendidikan dengan memanfaatkan cerita rakyat. Tidak hanya mengembangkan model pendidikan yang ada, tetapi juga menemukan pengetahuan untuk menyelesaikan masalah yang ada. Model pembelajaran yang diterapkan oleh guru adalah model pembelajaran yang dibuat oleh para ahli asing yang sering tidak relevan dengan nilai-nilai budaya siswa. Kondisi ini disebabkan oleh kurangnya model pembelajaran berbasis budaya lokal, tidak adanya upaya inovatif oleh guru untuk mengembangkan model pembelajaran berbasis budaya lokal, dan kurangnya kemampuan guru untuk mengatur dan menerapkan model pembelajaran berbasis budaya lokal. Dengan penelitian ini, cerita rakyat Bali memiliki nilai yang sangat strategis untuk pengembangan, pemberdayaan, dan pelestarian adat dan tradisi Bali.
\end{abstract}

Kata Kunci: Cerita rakyat; Internalisasi karakter; Model pembelajaran.

\section{ABSTRACT}

Folklore is a strategic media for the educational process, namely expository and humanistic, for children. Through folklore, children have a rational, realistic perspective, values and orientation in accordance with the culture they have. However, the development of digital media with all its

${ }^{*}$ Corresponding author: nimadearywidiastini.undiksha@gmail.com.

Copyright@ 2019 THE AUTHOR(S). This article is distributed under a Creative Commons Attribution-Share Alike 4.0 International license. Jurnal Kawistara is published by the Graduate School of Universitas Gadjah Mada. 
sophistication often removes the cultural values of children. Children lose their idol character that can be used as role models, alienated from their own cultural values, and lose their identity amidst massive developments in digital information. As Bourdieu's view of habitus as a set of values, practices and inner tendencies, where habitus can continue to develop (generative) and be transferred from one domain to another. In practice the presence of digital media turned out to have an impact on the uprooting of cultural values that should be accepted by children at an early age because it was replaced by technological developments. Understanding this phenomenon, reinforces the ideas of Borg and Gall, in this study the development of education by utilizing folklore, not only developing an existing educational model, but also finding knowledge to solve existing problems. The learning model applied by the teacher is a learning model created by foreign experts which is often not relevant to students' cultural values. This condition is caused by the lack of local culture-based learning models, the absence of innovative efforts by teachers to develop local culture-based learning models and the lack of teachers' ability to organize and implement local culture-based learning models. By this research, Balinese folklore has a very strategic value for the development, empowerment, and preservation of Balinese customs and traditions..

Keywords: Balinese folklore; Character internalization; Learning model; .

\section{INTRODUCTION}

Indonesia is one of the countries with complex cultural diversity and strong values. Indonesia are consisting of many ethnic groups, language dialects, large and small islands, religions and beliefs as well as various cultural features (Koentjaraningrat, 1981; Kasiyan, 2011). The values contained in culture and religions are excellent (adiluhung) guidelines used by citizens in their thoughts and behaviors. They help them in addressing whatever problems they may be facing, including character degradation. However, the country is being faced with different challenges such as fade of moral values, waning sense of nationalism, neglect of national identity, the existence of interethnic and inter-religious conflicts, as well as increasing issue of radicalism (The Wahid Institute, 2014). Concrete evidences showing degradation or demoralization in the formation of the nation's character include increasing prevalence of free sex, drug use, students brawls, motorcycle gangs brawls, women and children trafficking, corruption, collusion and nepotism, legal, juridical, and federal mafia, forest logging, excessive exploitation of natural resources, robbery and inhumane spoliation (Suastika and Sanjaya, 2017). Some of these are also experienced in the Balinese community. Conflicts between Songan and Banjar villages in Kawan Bangli due to mutual ridicule of football supporters, rancor between Budaga and Kemoning (Wirawan, 2015) villages in Klungkung because of Dalem Temple, fights between high school women's gangs in Denpasar uploaded via cellphones (Nvi, 2016), police officers accepting bribes from Dutch nationals as uploaded on the internet (Budi, 2013), and sexual abuse to underage children are examples of moral values have been degenerated in the community (Essra, 2016). In addition to the above case, degradation of morality has been seen in early childhood as indicated by the behavior of cheating on the work of his friends during tests, bullying friends, lying to parents and doing theft on a small scale.

Based on that case, this shows that the wisdom values of Balinese people have not been properly integrated into their process of education, both formal and non-formal (Megawangi, 2015; Suastika and Sanjaya, 2017). There are no structured and organized strategic efforts by teachers in developing materials, learning resources and models based on local culture (Sukadi, 2009), whereas the Center for Research and Development of the Curriculum Center in Indonesia (2007) emphasized the importance of the vision for local-based science in school based-curriculum. This was meant to develop a social science material in conformity with the local area excellence such as the living values and local cultures of the community the students belong. Learning material and models established based on this are very important in 
making social science education more meaningful and useful for the students (Sukadi, 2010). They can help in building their identity so that the global changes they are exposed to will not deprive them of local values existing in their social environment. This is supported by the Center for Research and Development of the Curriculum Center (2007) assertion that local values need to be developed and made to become a Social Science material placed in an equal position with global values, so as to strengthen the identity of the Indonesian nation. Therefore, the development of a local culture-based learning model is urgently needed in the midst of rapid globalization.

So far, there are many studies on character education, but studies investigating and developing Balinese folklore-based learning models that can practically be applied by elementary school teachers in carrying out social science instruction and developing students' literacy are limited (Suastika, 2015; Sukadi, 2010). Balinese folklore has been proven to be a strategic medium of instilling the values of Balinese characters. Therefore, a learning model established on it will help the students in exploring, formulating, describing, analyzing, internalizing and implementing knowledge, attitudes and moral behavior at school, in the family and their community on a daily basis (Lickona, 2013; Megawangi, 2015). Bandura (1971) explain, each individual will carry out the learning process by imitating what is in their environment, especially the behavior of others. In this case, each individual tends to imitate other people's behavior as a model behavior or example behavior. Thus, if the imitation is to gain reinforcement from within the individual, then the imitated behavior will be his behavior. The learning process is also an individual cognitive process and skills will be as a based of the individu in making a decision that are influenced by the imitation process. On the other hand, the steps (syntax) of need-based learning will facilitate the teachers in ensuring their sustainability. It is in line with the findings of Sukadi's research (2010) that the continuity of learning innovations developed by the experts without adequate reference to the real needs of teachers cannot be guaranteed. Sukadi (2010) argue innovation that mention above may not be relevant to the social and cultural environment of the society where the teachers carry out their professional duties. Folklore that are currently packaged in new forms, and presented in printed and electronic forms, should still be used in the process of educating children, especially in the formation of their character. Balinese folklore that is full of values and norms of life is very good to be used as a learning medium in order to foster a good attitude towards children and also to maintain Balinese traditions.

Methodologically, this research used educational research and development method (Borg and Gall, 1989). A literature study was conducted to analyze different types of Balinese folklore, character values in Balinese folklore, curriculum, graduate competency standards, basic competencies, learning resources, learning media, evaluation models and social science learning models for elementary schools. An empirical study was also conducted to analyze the activities of students in learning, teachers' activities, evaluation models, learning media and models applied by the teachers in social science education of elementary schools. An expert judge test was conducted to assess the relevance between theory and learning model; theory and model's syntax; and between students' learning needs and the developed learning model (Sugiyono, 2010). Data were collected using documentation study, observation, interview, and expert judge test. The instruments used were observation guidelines, interview guidelines, documentation study formats and expert judge test guidelines that were developed by previous researchers (Spradley, 1980). The research informants include students, teachers, librarian of Universitas Pendidikan Ganesha Social Science education experts and practitioners who were selected using purposive sampling technique. Purposive sampling technique was carried out considering that not all respondents had the ability to under- 
stand folklore. In this case the sample are 10 Balinese language teachers, 12 community leaders and 3 cultural figures. Their number and type were developed through the use of "snowball sampling technique" which was achieved by scrolling until data saturation was obtained. Data processing and analysis techniques were carried out qualitatively and quantitatively. Observation data, interviews and documentation studies were analyzed qualitatively by categorizing and classifying data as a whole based on their logical links and interpreted in the overall context of the research (Miles and Huberman, 1992). The expert judge test was analyzed quantitatively through Gregory test to assess the relevance of the learning model developed with its indicators (Koyan, 2007).

\section{DISCUSSION}

\section{Character Values in Balinese Folklore}

Christantyawati, et al (2018) provides an explanation that human life is characterized by the dynamics of meaning and sign, where it is realized that in human life, a culture has a dependency between one another which ultimately creates a story that is told from generation to generation, capable of producing a life trust. Folklore is part of a culture traditionally distributed and inherited, both in oral and sample forms, accompanied by gestures or assistive reminders from one generation to the other (Danandjaja, 2007). However, Balinese folklore is built through a collective culture passed down through different oral traditions from generation to generation and from one region to another according to their needs. For Balinese, folklore contains strategic values needed for the development of children's abilities such as listening, reading, understanding, analyzing, projecting, internalizing and determining values that can be used as guidelines in thinking, speaking and behaving in their daily lives. This is in accordance with Kartodirdjo (1986) submission that folklores are didactic (educational values embedded in them), heroic (show characters of helping others with various efforts), religious (believe in the existence of God and behave according- ly), worshipful (glorify the greatness of God with all His manifestations in various ways), traditional (possess cultural ideas consisting of cultural values, norms, habits, institutions, and customary law commonly practiced in an area), historical (present stories of past human life to guide future ones), and humorous (present stories and events as jokes).

Habitus is a historical product formed after humans are born and interact with society in space and time (Takwin, 2009). It is a set of values, practices and mental tendencies, both structured and structured (Barker, 2014) that can shape one's personality. Another expert, Plummer (2011), found that human's social actions not only requires habitus but more broadly, culture. As Bourdieu's idea in Qudsy et al. (2015) explains that language does not only have the generative ability to produce a number of infinite sentences, but also the originative ability to create something that is said. In practice, the languages in folklore that are loaded with the values of life need to be given to students, in shaping students to be of good character. As state of Christantyawati et al. (2018), the focus of attention on the main myths is not directed at how the human mind or mentality creates meaning from existing signs or references, but how the meaning of the developing myth can be communicated well. In practice, folklore must also be well communicated so that folklore listeners can understand the true meaning of life in folklore.

Culture, in this case, can be seen as a series of tools and creative responses which are constantly used in an attempt to solve problems. At its core, it contains symbolic languages, lines, stories, rituals, values, roles, identities, myths, beliefs, habits, and material objects that make up the human way of life. In practice, it is always alive and experiencing a change which is mostly championed, debated, modified, supported, and opposed by the members of the society.

Folklore are stories in the past that characterize every nation that has a diverse cultural culture including the cultural and historical wealth of each nation, which has a 
function as a means of moral and moral education. Balinese folklore can be used to correct, criticize, and evaluate various actions and behaviors that are not in accordance with customs and traditions in order to align them with agreed collective values (Cokrowinto, 1986). Paradigmatically, its functions can be described as follows:

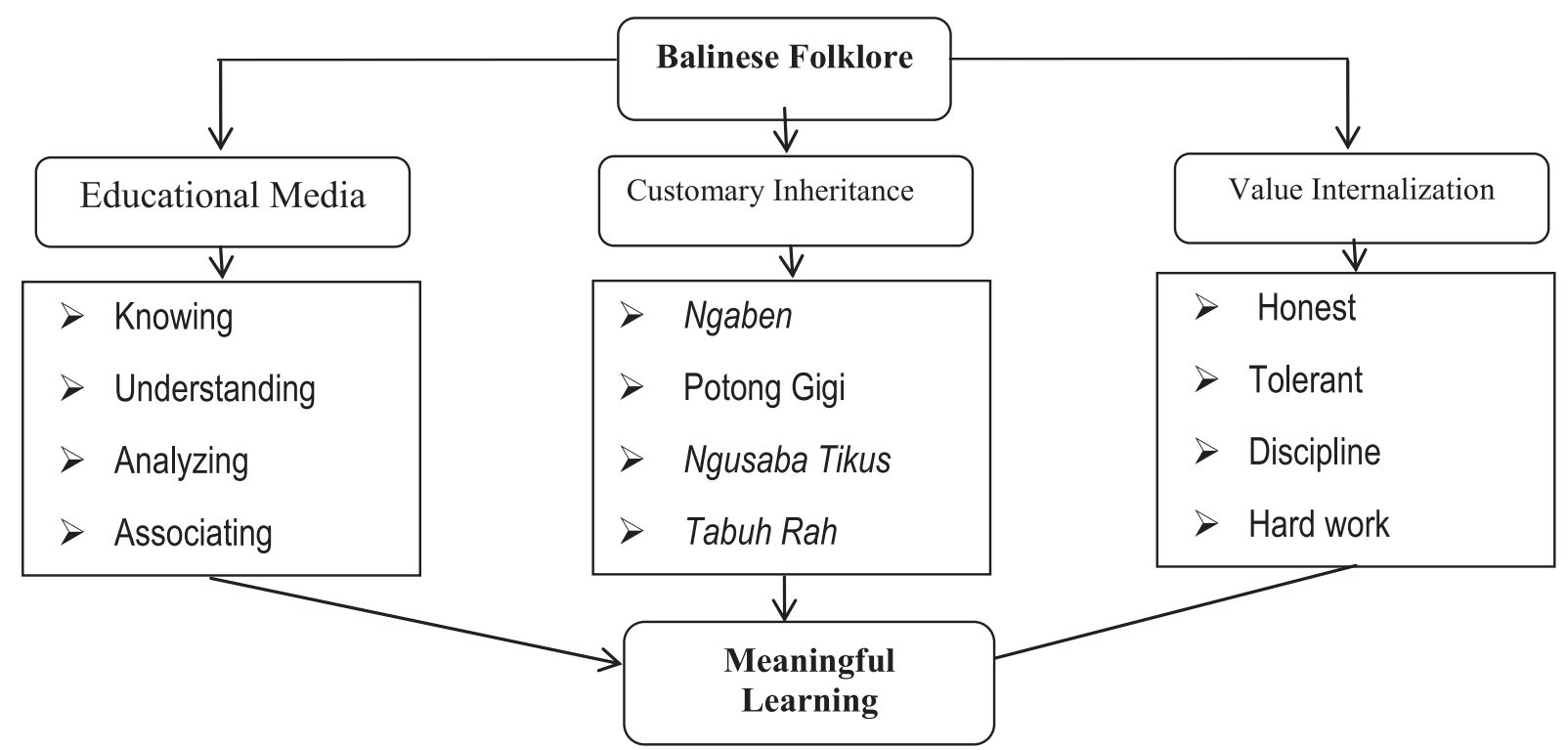

Figure 1.

Functions of Balinese Folklore

Matrix the Balinese folklore can be conveyed about the flow chart structure above, where in this case each customary inheri- tance has unique values and unique characteristics and media, as follows.

Table 1.

Matrix the Balinese Folklore

\begin{tabular}{llll}
\hline $\begin{array}{c}\text { Customary } \\
\text { Inheritance }\end{array}$ & Value Internalization & \multicolumn{1}{c}{ Education Media } & \multicolumn{1}{c}{ Characteristics } \\
\hline Ngaben & $\begin{array}{l}\text { Collaboration, } \\
\text { teamwork, hardwork, } \\
\text { respect a hero, heartfelt. }\end{array}$ & $\begin{array}{l}\text { Knowing, } \\
\text { Understanding, } \\
\text { Analyzing, Association }\end{array}$ & $\begin{array}{l}\text { Able to communicate well with } \\
\text { others, able to cooperate well in } \\
\text { the community, respect a hero. }\end{array}$ \\
\hline Potong Gigi & $\begin{array}{l}\text { Discipline, heartfelt, } \\
\text { wise, religious. }\end{array}$ & $\begin{array}{l}\text { Knowing, } \\
\text { Understanding, } \\
\text { Analyzing, Association }\end{array}$ & $\begin{array}{l}\text { Have high discipline, be wise in } \\
\text { making decisions, believe in God }\end{array}$ \\
\hline Ngusaba Tikus & $\begin{array}{l}\text { Respect the } \\
\text { environment, religious, } \\
\text { collaboration, sharing. }\end{array}$ & $\begin{array}{l}\text { Knowing, } \\
\text { Understanding, } \\
\text { Analyzing, Association }\end{array}$ & $\begin{array}{l}\text { Love the natural environment } \\
\text { for sustainable development, } \\
\text { build a balanced ecosystem, have } \\
\text { the skills to manage ecosystems } \\
\text { wisely }\end{array}$ \\
\hline Tabuh Rah & $\begin{array}{l}\text { Heartfelt, religious, } \\
\text { respect, tolerance, hard } \\
\text { work. }\end{array}$ & $\begin{array}{l}\text { Knowing, } \\
\text { Understanding, } \\
\text { Analyzing, Association }\end{array}$ & $\begin{array}{l}\text { Willing to sacrifice sincerely to } \\
\text { God, respecting all creatures } \\
\text { created by God, willing to } \\
\text { sacrifice to the nation and state }\end{array}$ \\
& & &
\end{tabular}


Balinese folklore has high religious social values for Balinese society, especially in maintaining their traditional traditions and values. It is a knot for their culture by making their cultural values and traditions known by the international community. Udu (2015) notes that oral tradition, as a wealth of national culture, is one of the valuable expressions of regional culture because it saves cultural values of traditional communities and also serves as the cultural root of a new society. Folk stories with religiously magical life values can be used to shape people into good ethics and make them adhere to the norms and values that are applicable in a particular society. This is in line with Santosa's ideas while examining performance art, that one of the dominant function of traditional performing arts is to provide education (Santosa et al., 2013)

Empirically, Balinese folklore has a recreational function, which is used in calming children when they are feeling bored while carrying out activities at school, home and in the community (Sibarani, 2013). Most schools apply it when they make national and local folklore books that available in their reading corners. Children feel bored after studying through scientific methods as stated by their teacher's lesson plan in the classroom, therefore, at break time they tend to be more enthusiastic in choosing folklore books that contain light stories. This is considered a recreational activity for them after they have been saturated with rigid classroom lessons (Danandjaja, 2007). Some teachers even gain the attention of these children by telling them folklore at the start of a lesson to build their enthusiasm to learn. Furthermore, innovative ones often make learning more enthusiastic by asking the students to bring or tell folklore before or after the lesson begins.

The selected folklore is adjusted to the material that will be discussed in the lesson in order to make it more interesting and easier for the students to understand and also serves as a kind of apperception activity for the students (Sukadi, 2009). Apart from the educational setting, they are also used as a recreational means for children in society. Reading or listening to Balinese folklore in leisure time becomes a very pleasant moment and has the ability to eliminate saturation. In fact, there is a current tendency to learn, understand and restructure various types of local wisdom that exist in the surrounding environment (Atmadja et al,. 2017). This condition makes it more attractive and meaningful for children in building their character values.

Balinese folklore also has an educational function which involves a process where children recognize, understand and implement values of goodness in their daily lives. The stories provide the children with knowledge about various social phenomena that occur in the community from a light perspective. It is also easy to understand and contains a rational and logical flow of thought. It is a strategic medium of developing knowledge, attitudes, and skills for children in order to make them understand the world in their own way and a reflection of life that is passed from one generation to the other based on the version of the speakers. It can be modified, revised and formulated as needed without reducing its meaning and essence.

According to Cokrowinto (1986), folklore provides a bridge of knowledge, values, ways of thinking, ideology, philosophy that has been tested to be preserved and developed for future generations. A high moral message is built in it to make children see achieving a better life as a way of life. It is a medium for creating awareness for them to change their behavior in response to the situations in their family, school and community.

Another function of Balinese folklore is the enhancement of inheritance of the values, customs, traditions, and culture of the community. It is a tradition of Indonesians, including Balinese, to continually cultivate cultural values through stories from one generation to the other (Danandjaja, 1991). Through this process, it is expected that the customs, traditions and cultural values of Bali should be everlasting and maintained despite the massive influence of foreign cultures. The folk- 
lore is used to formulate the social, political, religious and human life as well as the natural environments of the Balinese people (Suarka and Cika, 2014). For example, the story of "Bojog dadi Pecalang" (Monkey becomes a local security officer in Bali) provides an inspiration about the tasks and responsibilities of the community in maintaining security, cleanliness, and beauty of Bali natural environment. The message of morality delivered is very easy to understand because it pointed out that everyone is expected to understand their obligations, as citizens, in maintaining safety, peace, harmony, cleanliness, and natural beauty of the place where humans and other things live and grow (Okayana, 2017).

Folklore shows how to live with ethics, courtesy, empathy, tolerance, responsibility, discipline and how to be creative, sincere, honest, clean, healthy, intelligent, competitive, adaptive, humanist, humorous, and rational. The process of inheriting values, ideas, ideologies, ambitions, laws, customs, traditions, culture, traditional spatial planning, local wisdom, and others can be done through an internalization process that involves it. An example can be seen in the inspirational story of "Men Siap Selem" who maintained and protected her children in various ways from the strategies of "Men Kuwuk". It exhibits values of tenacity, responsibility, communication, deliberation, and mutual care among family members in achieving common goals. Heroically, Men Siap Selem tried to postpone Men Kuwuk's desire to prey on her undeveloped children by ensuring that they become hairy, able to fly and strong enough to escape (Riawan, 2017). This type of story motivates children to be strong when faced with obstacles in life. The attitudes and behaviors shown by Men Siap Selem and her children are a clear reference to how parents should think and behave in protecting their families from various threats as well as methods of preparing children to support family goals. Both stories can be a guideline for children to always work diligently, full of responsibility and discipline to achieve goals.

\section{The syntax of the Balinese Folklore- Based Social Science Learning Model}

In this study the type of classroom action research is carried out by involving the role of the teacher as a party who tells folklore in the process of social studies learning in elementary schools (Laboratory Primary School, University of Education Ganesha) which then proceed to explain the meaning and meaning implied in the story. On this occasion, the teacher emphasizes that the values of life in the story, which is very important for students to be known. It aims to shape the behavior of students who are better, understand the values and norms that exist in social life, so that students will have a right and good view of how to behave and behave. This attitude is expected to be applied throughout the life of students. The learning process by using folklore is recognized by teachers and students as more interesting, teachers are easier to teach because they act as storytellers. While students feel comforted and take lessons happily. In this case, when both parties can enjoy the teaching and learning process well, the message in the story can be conveyed well to students, which forms the structure of student cognition in accordance with the values and norms that apply in society.

Balinese folklore introduced to students through giving fairy tales in class, it can help students to have a good understanding of the values of life. Telling a folklore accompanied by an explanation of the value implied in the folklore can make students understand what is good and what is right, what is permissible or not. In this case the teacher certainly must be able to bring the story in an interesting way, and explain the meanings contained in the story that he read it. In this context, listening is an important point in the learning process, so that the teacher has a role as a good reader who is required to be able to make students focus on what they are told. Likewise, if students ask about things that are not understood about the folklore, the teacher as the reader of the story must have a correct understanding of the story reading out, and 
be able to answer correctly to students. Thus, the purpose of learning is to invest good values in students' life.

Habitus as Bourdieu's idea is understood as a set of values, practices and mental tendencies, both structured and structure (Bourdieu, 2010). Habitus can continue to develop (generative) and be transferred from one domain to another (Barker, 2014: 115-116). In this case there are three important things in the learning process that can be the basis for the formation of individuals, namely look, heard and listening so that they get a lesson from what is heard. There are three processes that can be traversed by humans to become individuals who have certain characteristics, namely seeing, hearing and learning something from what they see and hear. Looking, someone at an early stage will see something that the brain responds to asking the trusted party to get an answer to what they see. Listening, not just to make someone know, but at the stage of planting the concept of a person's brain will digest the answers they receive. Learning by hearing answers and becoming aware, a person will experience the process of learning something about what he hears. Based on Bourdieu, there are three elements that influence a person's actions, namely habitus, capital and domain. In social space, individuals with their habitus relate to other individuals and various social realities that produce actions in accordance with their domains and capital (Takwin, 2009). Before entering the element of capital and realm, it is necessary to understand that the formation of one's habitus that makes a person have a certain character is the role of someone outside himself, namely a teacher who gives an understanding of good characters to his students through folklore.

Literature and empirical studies (Suastika, 2018) showed that the development of Social Science learning model based on Balinese folklore must be founded on the philosophy of education as regards rationalism, empiricism and pragmatism, constructivist education theory and scientific approach, in line with the 2013 curriculum of Indonesia (research-based and problem solving-based learning, in accordance with the learning principles), as well as cultural values, needs of students and easy application by teachers. Paradigmatically, the foundation for developing a Balinese folklore-based social science learning model can be described as follows:

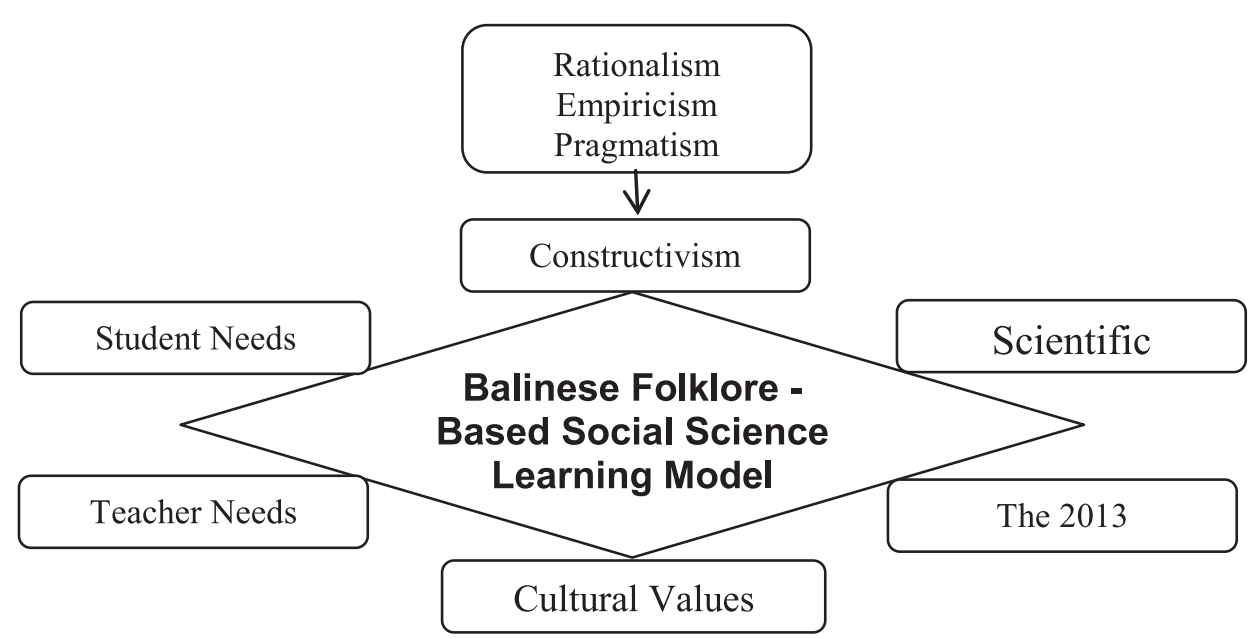

Figure 2.

Development of Balinese Folklore-Based Social Science Learning Model 
In a basic structured philosophy and empirical basis, the development of social science learning models based on Balinese folklore can be described as follows: Firstly, the model must be based on the educational philosophy of rationalism, empiricism, and pragmatism. Rationalism believes that knowledge is found in the form of unlearnt ideas as an innate gift from God. Empiricism is of the opinion that reality is the experience of objects obtained through the sensing process, such that knowledge is the correspondence between ideas and sensory objects (Sukadi, 2009). Pragmatism, on the other hand, believes that reality is human experience, so knowledge is a consequence of actionable ideas (Gredler, 1991). The learning model developed must be able to improve students deductive, inductive and praxis ways of thinking.

Secondly, it is founded on the constructivist learning theory, which believes that learning is a construction process for students based on their experience as well as the new things they gathered in the educational process. According to this theory, knowledge is not an objective reality that exists outside the human, on the contrary, it is an active construction in their mind that comes as a result of their active interaction with the environment through the application of their pre-existing structures of knowledge and previous experiences. Thus, constructivism, in this case, is used in the context of developing knowledge, values, and attitudes, as well as patterns of action that are actively constructed by the subjects (Sukadi, 2009). Learning is defined as learners active process in constructing meaning through the process of assimilation and relating of experience or materials studied with previous understanding about a topic. The learning process is not seen as the acquisition of information only in one direction i.e. from the outside into the student's self, but as a way of giving meaning to experiences through the process of assimilation, accommodation and calibration which leads to the breakdown of cognitive structure (Gredler, 1991). This is not done individual- ly but through interactions in unique social networks formed both inside and outside the classroom. According to Suparno (1997) the active process of constructing knowledge will greatly influence students learning because they create meaning from what they see, hear, feel and experience. Therefore, the construction of meaning is influenced by (1) initial knowledge; (2) construction of meaning is a continuous process, therefore, whenever someone is dealing with a new phenomenon or problem, a reconstruction will be held, either strongly or weakly; (3) learning is not an activity to gather facts, but rather a development of thinking by making new understandings; (4) the actual learning process takes place through the stimulation of further thoughts when one's initial scheme/knowledge is in doubt, thus, an imbalance situation (disequilibrium) is a good situation to spur learning; (5) learning outcomes are influenced by student's experience of the physical world and environment; (6) the results of one's learning depend on what the learner has already known, such as concepts, goals, and motivations that influence the interaction with the material being studied (Gredler, 1991).

Thirdly, the model must be in line with the scientific approach by covering the process of observation, inquisition, reasoning, trials, and presentations (Republik Indonesia, 2016). Scientific learning process touches three domains, namely attitudes, knowledge, and skills at once. The attitude domain covers the transformation of substance or teaching material so that the students "know why", the skills domain covers "know how" while the knowledge domain has to do with "know what". This will, however, help in improving and balancing between the ability to be a good human being (soft skills) and the skills and knowledge needed to live a decent life (hard skills). The attitude competence is obtained through the activities of receiving, running, appreciating, living, and practicing, skills competence by observing, questioning, trying, reasoning, presenting, and creating while knowledge competence is obtained by 
remembering, understanding, implementing, analyzing, evaluating, and creating. The students are subjects with the ability to actively seek, process, construct and use knowledge (Sukadi, 2009).

Fourthly, the model is in accordance with the principles of the 2013 curriculum. This include from being told to finding out; from the teachers as the only source of information to multi sources; from a textual approach to a process of using scientific approach; from content-based to competency-based learning; from partial to integrated learning; from learning that emphasizes single answer to those with multi-dimensional answers; from verbalism learning to applicable skills; a balance between physical skills (hard skill) and mental skill (soft skills); prioritizing civilization and empowering students as lifelong learners; applying values by giving model, developing willingness, developing creativity, learning at home, at school, and in the community; applying the principle that anyone is a teacher, anyone is a student, and everywhere is classroom; using information and communication technology to improve the efficiency and effectiveness of the lessons, and recognizing individual and students cultural background diversity (Republik Indonesia, 2016).

Fifthly, the learning model is in line with the local cultural values that acquiring knowledge comes from the interaction process between physical objects, mind (manah), soul (budhi) and spirit (atman) which comes from God (Sukadi, 2009). The five senses initially direct attention to various physical objects in order to make the body achieve physical goals. The mind realizes and controls the relationship between the five senses and the physical objects. The soul gives awareness of morality to the mind to achieve physical and mental goals. The spirit is the highest source of consciousness and a manifestation of God that ensouls human life. In relation to this, ideologically, students are seen as mono-pluralistic human beings with various abilities such as spiritual, moral, intellectual, social, kinesthetic, and personal intelligence that must be developed (Sukadi, 2010).

Sixthly, the learning model is in accordance with the needs of the teachers. It addresses the pedagogical, academic, personal, and social competencies as well as the level of technological literacy of the teachers (Suastika, 2015). It can be easily applied with respect to their professional culture. Sukadi, (2009) reveals that innovation that is not in line with the socio-cultural values of teachers makes them feel strange in their profession. Just like the facilities and infrastructure used in the learning process, it should also be available in the socio-cultural environment where the educational practices take place because of its usefulness in developing students multiple skills (Yaumi, 2014).

Seventhly, the learning model is in line with students learning needs such as the cognitive and moral developments as well as their characteristics and socio-cultural conditions. According to Piaget in Gredler (1991), the level of cognitive development can be divided into four stages, namely sensorimotor, pre-operational, concrete and formal operational stages. Based on this classification, elementary school students are placed at a concrete operational period because of their characteristics of being able to see the views of other people/children, having logical ways of thinking about concrete objects and thinking in a way that is not bound to perceptual cues. The students moral development starts from pre-conventional, conventional and post-conventional. In the pre-conventional period, they can be oriented about punishment and obedience, responsive to rules (based on good and bad): if they act bad, they will be punished and when they act good, they will be rewarded (relationships between people are considered to be transactional). In the conventional period, they can be oriented about what it takes to be good boys or sweet girls (making others happy and helping others), laws and regulations (behavior is considered right when maintaining social rules, performing obligations, and respecting authority). In the post-conventional period, 
they can be oriented about social contract (understanding right and wrong based on individual rights and proven norms) and universal ethical principles (right and wrong are determined by conscience) (Gredler, 1991). A student's character can be active, passive, ex- trovert, introvert, individual, social and others. It determines the learning methodology to be applied by teachers in their instructional process. Based on this foundation, the syntax of Balinese folklore-based social science learning model can be described as follows
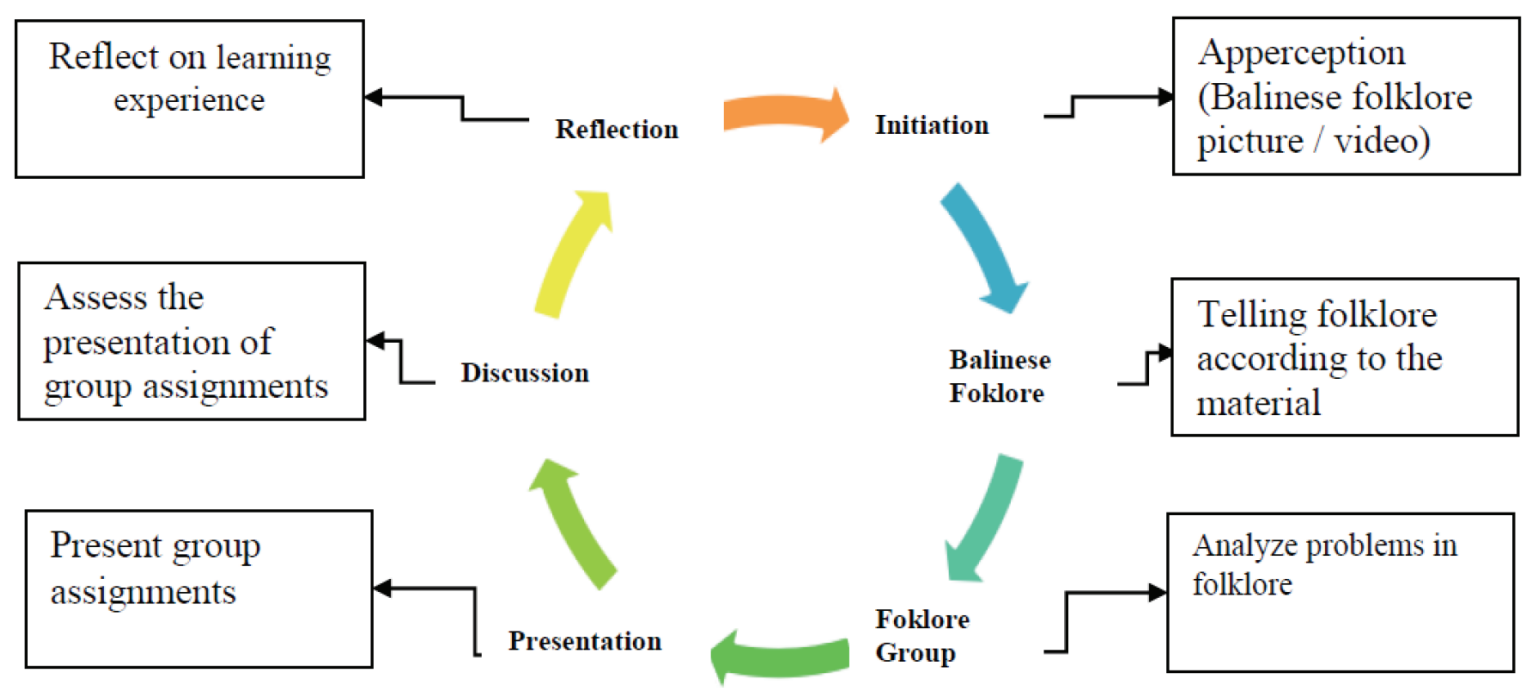

Figure 3.

Syntax of Balinese Folklore-Based Social Science Learning Model

The judge's test results conducted by Social Sciences Education experts and Social Sciences teachers on the syntax of Balinese folklore-based Social Sciences learning models are: (1) the learning steps have good consistency, because between the first activity with the next activity is systematic and continuous, (2) the activities of students in the learning steps, to achieve the learning objectives are in a very good category, because the construction process is carried out by students according to their socio-cultural conditions with the facilitator and motivator from the teacher, (3) the theoretical basis used as the basis for developing a good learning model, because it fits with social learning theory where the process of acquiring knowledge occurs through group activities, (4) teacher activities in the learning steps are in the good category, because it is easy to apply by teachers with clear and rational instructions, (5) the values built into the categorized learning steps are very good, because they are able to develop students knowledge, attitudes and skills in internalizing values local cultural values, (6) materialy discussed in the learning steps are in the good category, because the material studied by students is contextual, in accordance with the real problems that exist in people's lives, and (7) learning activities in providing fun activities for students are in a very good category, because it is able to build learning that is challenging and fun for students to take part in the learning process that takes place.

\section{CONCLUSION}

Balinese folklore has a very strategic value for the development, empowerment, and preservation of Balinese customs and traditions. In this case, in line with the idea of Christantyawati, et al (2018) which explains the myth, where myth has always been the fundamental meaning of the symbol of people's lives, even though modern technology has become another choice. Children develop the ability to listen, read, understand, analyze, project, internalize and determine values that 
can be used as guidelines in thinking, speaking and behaving in accordance with Balinese values and culture. It also serves as a recreational means, educational facility, and means of inheritance. The development of Balinese folklore-based social science learning model must be guided by the philosophy of education of rationalism, empiricism, and pragmatism, constructivism education theory, and scientific approach. It should also be in line with the 2013 curriculum in Indonesia (research-based and problem-solving learning principles), cultural values, students needs and easy application by teachers. Thus, the syntax of the learning model begins with initiation, Balinese folklore, folklore group, presentation, discussion, and reflection. The syntax of the learning model is able to make the learning process to be fun, challenging, value-based, contextual, and meaningful for students life. This is caused by the syntax of the folklore based of social science learning model for elementary school in Bali be able to construct, conduct group discussions, work together, analyze, and conclude various learning experiences obtained in learning activities.

\section{BIBLIOGRAPHY}

Atmadja, N. B., Atmadja, A. T., and Maryati, T. 2017. Agama Hindu, Pancasila dan Kearifan Lokal Fondasi Pendidikan Karakter. Singaraja: Pustaka Larasan.

Badan Penelitian dan Pusat Pengembangan Kurikulum. 2007. Materi Sosialisasi dan Pelatihan Kurikulum Tingkat Satuan Pendidikan (KTSP) Sekolah Menengah Pertama. Jakarta: Departemen Pendidikan Nasional.

Bandura, Albert. 1971. Social Learning Theory. Marristown, N.J. General Learning Press

Barker, C. (2014). Kamus Kajian Budaya. Yogyakarta: Kanisius.

Borg, W. R., and Gall, M. D. (1989). Educational Research: An Introduction (5 ${ }^{\text {th }}$ ed.). New York: Longman.
Bourdieu, Pierre. 2010. Arena Produksi Kultural: Sebuah Kajian Sosiologi Budaya (terjemahan). Yogyakarta: Kreasi Wacana.

Budi, Taufik. 2013. Bule Belanda Suap Polisi Bali Ternyata Presenter TV. Okenews. (Online). Accessed on 11 April 2019 (https://news.okezone. $\mathrm{com} / \mathrm{read} / 2013 / 04 / 05 / 340 / 787065 /$ bule-belanda-suap-polisi-bali-ternyatapresenter-tv).

Cokrowinto, S. 1986. Manfaat Folklor bagi Pembangunan Masyarakat" dalam Kesenian, Bahasa, dan Folklor Jawa. Yogyakarta: Proyek Penelitian dan Pengkajian Kebudayaan Nusantara (Javanologi) Direktorat Jenderal Kebudayaan Departemen Pendidikan dan Kebudayaan.

Danandjaja, J. (1991, 26-27 Februari 1991). Folklor Nusantara dan Jepang: Suatu Studi Perbandingan. Paper presented at the Seminar Tradisi Budaya Indonesia Jepang, Jakarta.

Danandjaja, J. 2007. Folklor Indonesia: Ilmu Gosip, Dongeng, dan Lain-lain. Jakarta: PT Pustaka Utama Grafiti.

Essra, Try Reza. 2016. Kejahatan Seksual Imbas Dari Degradasi Moral. AntaraNews.Com. (Online). Accessed on 11 April 2019. Available at $h$ ttps:// www.antaranews.com/berita/585283/ kejahatan-seksual-imbas-dari-degradasimoral.

Gredler. 1991. Learning and Instruction: Theory and Practice (Second ed.). New Jersey: Prentice-Hall.

Kartodirdjo, S. 1986. Suatu Tinjauan Fenomenologis tentang Folklore Jawa" dalam Kesenian, Bahasa, dan Folklor Jawa. Yogyakarta: Departemen Pendidikan dan Kebudayaan.

Kasiyan, 2011. Quo-Vadis Multikulturalisme Dalam Historis dan Historiografi Seni Rupa Indonesia. Kawistara. Volume 1 (2): 103-212. 
Kodir, Faqihuddin Abdul Kodir. 2011. Gender Justice and The Cultural Dimension of Religion: A Proposal to Apply The Prophetic Traditions (the Hadiths) in Promoting Gender Justice Among Indonesia Muslims. Kawistara. Volume 1, No. 3, Pg. 213-320

Koentjaraningrat. 1981. Pengantar Ilmu Antropologi (Vol. Radar Jaya Offset): Jakarta.

Koyan. 2007. Statistik Multivariat Disertai Petunjuk Analisis dengan SPSS. Singaraja: Program Pascasarana Universitas Pendidikan Ganesha.

Lickona, T. 2013. Educating for Character. New York: Batam Book.

Megawangi, R. 2015. Semua Berakar Pada Karakter. Jakarta: Lembaga Penerbit Fakultas Ekonomi Universitas Indonesia.

Miles, M. B., and Huberman, A. M. 1992. Analisis Data Kualitatif Buku Sumber tentang Metode-Metode Baru (T. R. Rohidi, Trans.). Jakarta: UI Press.

Nvi, Rez. 2016. Heboh Video Perkelahian Dua Gadis Bali. NusaBali.Com. (Online). Accessed on 11 April 2019. Available at https://www. nusabali.com/berita/8516/heboh-videoperkelahian-dua-gadis-bali.

Christantyawati, N., Walensa, L., and Juraman, S. R. 2018. Budaya Unu Tanah dan Budaya Lio Menyoal Narasi Mitos Tanah, Hermeneutika Alam, dan Komunikasi Lintas Generasi. Kawistara, Volume 8, No. 1, Pg. 61-74.

Okayana, P. 2017. Satua Bali : I Lutung Dadi Pecalang. Retrieved May $11^{\text {th }}$, 2018, from http://satua-bali.blogspot. com/2013/08/satua-bali-i-lutung-dadipecalang.html.

Plummer, K. 2011. Sosiologi: The Basics. Jakarta: Raja Grafindo Persada.

Qusdy, Zuhri Saifuddin. Irwan Abdullah. Qodir Zuly. 2015. Kasuran Dalam
Beragam Sudut Pamdang Merunut Jejak Jejak Cerita Tidur Tanpa Kasur di Dusun Kasuran. Kawistara, Volume 5, No. 2, Pg. 184-199.

Republik Indonesia. 2016. Peraturan Menteri Pendidikan dan Kebudayaan Republik Indonesia Nomor 22 Tahun 2016 tentang Standar Proses Pendidikan Dasar dan Menengah. Jakarta: Direktur Jenderal Peraturan Perundang-Undangan Kementerian Hukum dan Hak Asasi Manusia Republik Indonesia.

Riawan, N. 2017. Satua Bali: I Siap Selem. Retrieved June $26^{\text {th }}, 2018$, from $h$ ttps:// msatuabali.blogspot.com/2017/01/ satua-bali-i-siap-selem.html

Santosa, D. H., Haryono, T., and Soedarsono, R. M. (2013). Seni Dolalak Purworejo Jawa Tengah: peran Perempuan dan Pengaruh Islam Dalam Seni Pertunjukkan. Kawistara: Jurnal Sosial dan Humaniora, 3(3), 227-334.

Sibarani, R. 2013. Folklor Sebagai Media dan Sumber Pendidikan: Sebuah Ancangan Kurikulum dalam Pembentukan Karakter Siswa Berbasis Nilai Budaya Batak Toba. In S. Endraswara (Ed.), Folklor Nusantara: Hakikat, Bentuk, dan Fungsi. Yogyakarta: Penerbit Ombak (Anggota IKAPI).

Spradley, J. P. 1980. Participant Observation. New York: Holt, Rinehart and Winston.

Suarka, I. N., and Cika, I. W. 2014. Pendayagunaan Folklor Sebagai Sumber Ekonomi Kreatif di Daerah Tujuan Wisata Bali. ATAVISME, 17(1), 71-83.

Suastika, I. N. 2015. Rekonstruksi Model Pembelajaran Karakter Berbasis Lokal Genius (Studi Pengembangan Model Pembelajaran PPKn Pada Siswa SMP di Propinsi Bali). Singaraja: Universitas Pendidikan Ganesha. 
Suastika, I. N., and Sanjaya, D. B. 2017. Implementing Sadguna-Based Character Teaching Model in Civics Education at Junior high school Laboratorium Undiksha. Paper presented at the 2nd International Conference on Innovative Research Across Disciplines (ICIRAD 2017), Singaraja.

Sugiyono. 2010. Metode Penelitian Kuantitatif Kualitatif dan RandD. Bandung: Alfabeta.

Sukadi. 2009. Belajar dan Pembelajaran (Bermuatan Konsep-Konsep Kearifan Lokal). Singaraja: Universitas Pendidikan Ganesha.

Sukadi. 2010. Pengembangan Model Pembelajaran PKn Berbasis Yadnya. Singaraja: Universitas Pendidikan Ganesha.

Suparno. 1997. Filsafat Konstruktivisme dalam Pendidikan. Yogyakarta: Penerbit Kanisius.

Takwin, B. 2009. Proyek Intelektual Pierre Bourdieu:Melacak

Asal-Usul
Masyarakat, Melampaui Oposisi Biner dalam Ilmu Sosial. In R. Harker, C. Mahar, and C. Wilkes (Eds.), Habitus X Modal) + Ranah = Praktik Pengantar Paling Komprehensif kepada Pemikiran Pierre Bourdieu. Yogyakarta: Jalasutra.

The Wahid Institute. 2014. Laporan Tahunan Kebebasan Beragama/Berkeyakinan dan Intoleransi 2014 (Utang Warisan Pemerintah Baru). Jakarta: The Wahid Institute.

Udu, S. 2015. Tradisi Lisan Bhanti-Bhanti Sebagai media Komunikasi Kultural Dalam Masyarakat Wakatobi. Humaniora, 27(1), 53-66.

Yaumi, M. 2014. Prinsip-Prinsip Desain Pembelajaran Sesuai dengan Kurikulum 2013. Jakarta: Kencana.

Wirawan, I Komang Arba. 2015. Dari Konflik Desa Ke Layar Kaca: Analisis Wacana Liputan Bali TV Dalam Kasus Kemoning- Budaga, Klungkung, Bali. Disertasi. Program Studi Kajian Budaya. Denpasar: Universitas Udayana. Not Publish. 